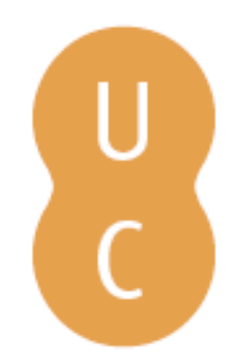

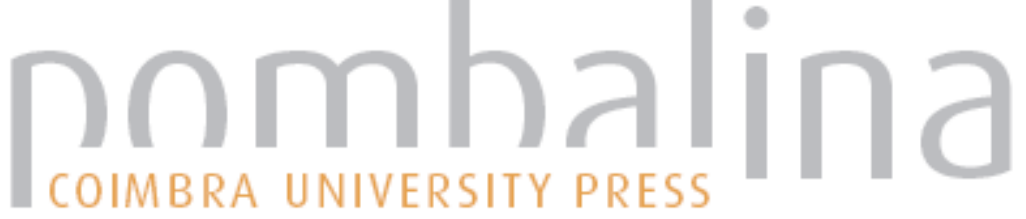

\section{Unsteady phenomena affecting the propagation of surface fires}

Autor(es): $\quad$ Morvan, Dominique

Publicado por: Imprensa da Universidade de Coimbra

URL

persistente: $\quad$ URI:http://hdl.handle.net/10316.2/34151

DOI: $\quad$ DOI:http://dx.doi.org/10.14195/978-989-26-0884-6_55

Accessed : $\quad$ 26-Apr-2023 14:37:00

A navegação consulta e descarregamento dos títulos inseridos nas Bibliotecas Digitais UC Digitalis, UC Pombalina e UC Impactum, pressupõem a aceitação plena e sem reservas dos Termos e Condições de Uso destas Bibliotecas Digitais, disponíveis em https://digitalis.uc.pt/pt-pt/termos.

Conforme exposto nos referidos Termos e Condições de Uso, o descarregamento de títulos de acesso restrito requer uma licença válida de autorização devendo o utilizador aceder ao(s) documento(s) a partir de um endereço de IP da instituição detentora da supramencionada licença.

Ao utilizador é apenas permitido o descarregamento para uso pessoal, pelo que o emprego do(s) título(s) descarregado(s) para outro fim, designadamente comercial, carece de autorização do respetivo autor ou editor da obra.

Na medida em que todas as obras da UC Digitalis se encontram protegidas pelo Código do Direito de Autor e Direitos Conexos e demais legislação aplicável, toda a cópia, parcial ou total, deste documento, nos casos em que é legalmente admitida, deverá conter ou fazer-se acompanhar por este aviso.

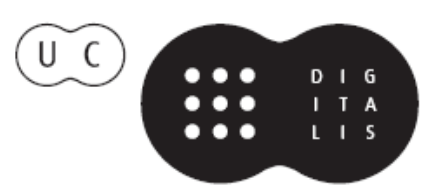




\section{ADVANCES IN}

Forest Fire

\section{RESEARCH}

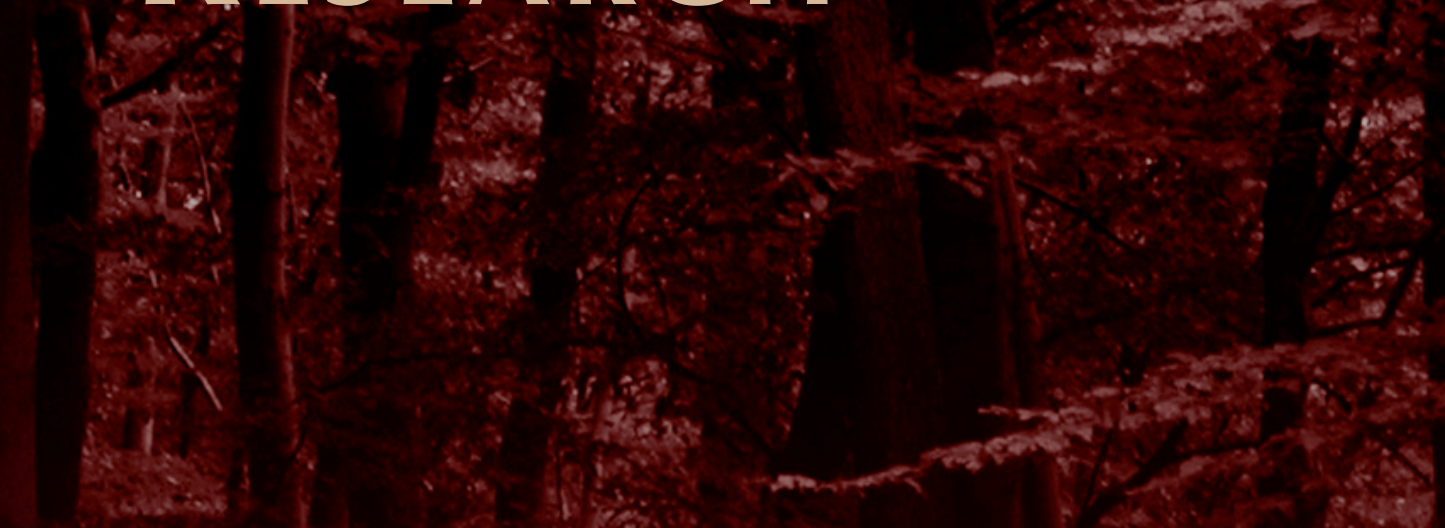

\section{DOMINGOS XAVIER VIEGAS}

\section{EDITOR}




\title{
Unsteady phenomena affecting the propagation of surface fires
}

\author{
Dominique Morvan
}

Laboratoire de Mécanique, Modélisation et Procédés Propres (M2P2)

UMR 7340 CNRS, Aix-Marseille Université, Ecole Centrale de Marseille

UNIMECA 60 rue Joliot Curie, Technopôle de Château Gombert

13453 Marseille cedex 13 France dominique.morvan@univ-amu.fr

\begin{abstract}
The unsteadiness coming from thermo-convective and shear instabilities or from the time variations of the external conditions affecting the fire (wind gusts for example), affecting the propagation of a surface fire, has been studied numerically using a multiphase approach. Two regimes of propagation (plume dominated and plume driven) have been identified, governed by two forces: the buoyancy resulting from the density gradient inside and outside the plume and the inertia of the wind. The degree of non-linearity associated with these two physical mechanisms, can explain the magnitude of unsteadiness of the fire behaviour. It participates also of the impact (sometimes linear and sometimes strongly non-linear) of the impact of wind conditions upon the fire spread. For weak wind conditions (exhibiting potentially a more non linear behaviour), a sinusoidal time variation of the wind speed has been tested with five frequencies $(0.25,0.5,1,2$ and $3 \mathrm{~Hz})$ nearly equal to the frequency $(1.4 \mathrm{~Hz})$ characterizing the thermo-convective instability (in assimilating the fire front as a pool fire) and to the shear instability $(0.26 \mathrm{~Hz})$.
\end{abstract}

Keywords: surface fire, multiphase model, wind/fire interaction

\section{Introduction}

With ambient temperature and relative air humidity, the wind is certainly one of the most important weather parameter affecting the conditions of ignition and propagation of wildland fires. Various experimental studies carried out at small scale in a wind tunnel and at large scale on the field, have highlighted a power law relationship (ROS $\sim \mathrm{U}_{\mathrm{W}}{ }^{\mathrm{B}}$ ) between the rate of spread (ROS) of a surface fire and the wind velocity $\left(\mathrm{U}_{\mathrm{W}}\right)[1,2,3,4,5]$. The fact that the wind's exponent $\mathrm{B}$ varies from 0.4 [3] to 2 [5], shows that this relationship is not fully understood. Direct observations of fires in grassland [6], have highlighted that the curve representing the relation ROS versus $U_{W}$ can be decomposed in three zones: a linear zone (wind's exponent B nearly equal to one), bounded by two non-linear zones for weak $(B>1)$ and strong $(B<1)$ wind conditions. Because experimental fires must be conducted in safe conditions, the range of variations of wind conditions cannot be extended sufficiently, to observe in all cases, these changes of fire behaviour. Numerical simulations performed in shrubland, which are not submitted to the same constraints, have been able to reproduce this kind of behaviour [7]. Analysis of experimental results obtained in a fire wind-tunnel [8], seem indicating that sudden changes of slope in the curve ROS vs $U_{W}$ can be attributed to a change in the main mode of heat transfer (by convection and radiation) between the flame and the solid fuel layer. It is well known that the relative importance between these two mechanisms of heat transfer, is strongly affected by the view angle between the flame and the unburned fuel and consequently by the trajectory of the flame (more or less vertical). This trajectory is affected by two forces along two directions: vertically the buoyancy and horizontally the inertial force of the wind. The relative importance of these two forces can be evaluated from a non dimensional parameter, the Byram's convective number [9]:

$$
N_{C}=\frac{2 g I_{B}}{\rho C_{P} T_{0}\left(U_{W}-R O S\right)^{3}}
$$


where $g$ is the acceleration of gravitation, $I_{B}$ is the fireline intensity, $\rho, C_{P}$, and $T_{0}$ are the density, the specific heat and the temperature of the ambient air.

From the value taken by this similitude parameter, two great regimes of fire propagation have been identified:

- For $N_{C} \gg 1$, the plume dominated fires, characterized by a flame trajectory more or less vertical, a general trend of the air flow (near the fire) to be symmetrically aspirated by the fire front,

- For $N_{C}<<1$, the wind driven fires, characterized by a flame horizontally sheared by the wind flow, pushing hot gases toward the vegetation layer located ahead of the fire front,

The propagation of surface fires can be affected by unsteady phenomena coming from the fire itself (internal fluctuations of the fire intensity) and from variations of external parameters such as time variations of the wind velocity (gusts). Depending of the fire propagation regime (plume dominated or wind driven) the consequences for the forecasting of fire behaviour are more or less significant. Previous experimental observations have shown that the relationship between the fire rate of spread and the wind velocity was not as straightforward (as a monotonous curve) in all wind conditions [10, $11]$.

It is in this general context, that the present study has been conducted, in focussing our attention on the effects of these two sources of unsteadiness upon the behaviour of a surface fire in propagation through a homogeneous fuel layer representative of grassland.

The study was based on numerical simulations, in using a multiphase formulation, details of the physical and numerical models can be found in previously published articles [7, 9, 12, 13].

In the first part of the paper, unsteady signals of fireline intensity have been analyzed for various quasi steady wind conditions ( $\mathrm{U}_{\mathrm{W}}$ ) ranged between 1 and $25 \mathrm{~m} / \mathrm{s}$ (10m open wind velocity). With these values, the simulations covered a large range of conditions of propagation from plume dominated to wind driven fires $\left(\mathrm{N}_{C}\right.$ ranged nearly between 0.1 and 1000). Then the effects of a sinusoidal time variation of the wind flow (representing wind gusts) have been explored for relatively moderated wind conditions $\left(\mathrm{U}_{\mathrm{W}}=2 \mathrm{~m} / \mathrm{s}, \Delta \mathrm{U}_{\mathrm{W}}=+/-1 \mathrm{~m} / \mathrm{s}\right)$. In this case, four frequencies were tested $0.25,0.5,1,2$ and $3 \mathrm{~Hz}$.

\section{Physical multiphase model}

The numerical simulation of the behaviour of wildland fires is very challenging and can be qualified as a complex multi-scale and multi-physics problem. The main difficulty results from the wide spectral band of length scales, associated to physical mechanisms governing the fire behaviour (atmospheric turbulence, combustion, pyrolysis, radiation heat transfer ...) which are for most of them non-linear. Even if we limit the description of the problem to the immediate neighbourhood of the fire front, a large range of spatial scales are concerned: the turbulent integral length scale of the boundary layer flow above the canopy (more or less equal to the height of the canopy, $0.7 \mathrm{~m}$ here), the corresponding Kolmogorov micro-scale $(<1 \mathrm{~mm})$, the length of extinction characterizing the vegetation layer $(0.5 \mathrm{~m}$ here), the flame thickness ( $500 \square \mathrm{m}$ for a hydrocarbon flame) [9]. Of course, it is impossible to explicitly take into account all these length scales, the effects of the smallest ones (Kolmogorov microscale and flame thickness) must be reproduced using physical models [15]. In the same order of idea, it is impossible to reproduce with all details, the structure of the vegetation layer. In place of representing in details all the elements constituting the vegetation (foliage, twigs, trunk), an averaging procedure has been introduced which consists in representing the vegetation as an equivalent sparse porous media. This approach can be assimilated as a sort of homogenization step, is often referenced in the literature as a multiphase formulation of forest fire modelling $[7,12,14]$. The main advantage of this formulation is the possibility of taking into account all the terms of interaction between the gas 
phase and the vegetation, without the necessity of representing in detail the very complex interface (fractal) between these two phases. The numerical simulations (2D) have been carried out in a computational domain, $170 \mathrm{~m}$ long and $35 \mathrm{~m}$ high, inside which a $150 \mathrm{~m}$ long and $0.7 \mathrm{~m}$ high homogeneous vegetation layer has been positioned (see Figure 1). The inlet wind flow has been reproduced with a logarithmic velocity profile (Eq. 2) at the left end side of the domain (the constant A was adjusted to ensure a known value of the wind velocity $10 \mathrm{~m}$ above the ground level), $\mathrm{z} 0=0.01$ $\mathrm{m}$ corresponding to a nude soil. A $20 \mathrm{~m}$ long nude zone (without any vegetation) has been built near the entrance, to ensure the establishment of the boundary layer flow (see Figure 1).

$$
U_{X}(z)=A \times U_{10} \times \operatorname{Ln}\left(\frac{z+z_{0}}{z_{0}}\right)
$$

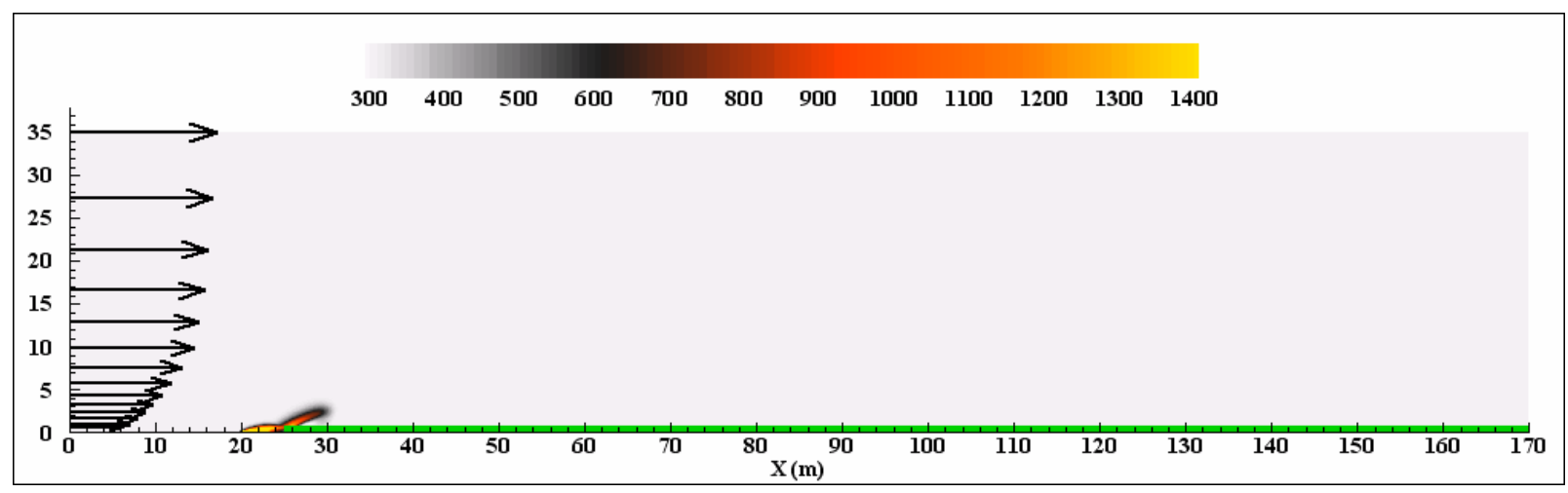

Figure 1. Computational domain and boundary conditions.

The vegetation layer (here a homogeneous grass) has been represented using the set of physical properties from data collected on the field [16]. To guarantee an optimal accuracy, the simulations have been performed using a dynamic adaptive mesh attached to the fire front (positioned from the first pick of temperature inside the vegetation). The size of the grid mesh in the vicinity of the fire front, has been adjusted to guarantee that the radiation heat transfer and the turbulent flow inside the vegetation were correctly reproduced $[9,17]$.

Table 1. Solid fuel physical properties and external conditions imposed in the present numerical simulations (Anderson 1982).

\begin{tabular}{cc}
\hline \hline Solid fuel density $\left(\mathrm{kg} / \mathrm{m}^{3}\right)$ & 500 \\
Volume fraction $\times 10^{3}$ & 2 \\
Fuel moisture content (FMC) $(\%)$ & 10 \\
Fuel depth (m) & 0.7 \\
Fuel load $(\mathrm{t} / \mathrm{ha})$ & 7 \\
Surface area to volume ratio $\left(\mathrm{m}^{-1}\right)$ & 4000 \\
Length of extinction $(\mathrm{m})$ & 0.5 \\
Leaf Area Index $(\mathrm{LAI})$ & 2.8 \\
10m open wind velocity $(\mathrm{m} / \mathrm{s})$ & $1-25$ \\
\hline \hline
\end{tabular}

Plume dominated fires are supposed to be mainly governed by the buoyancy force resulting from the difference of density between the external atmosphere and the hot gases inside the thermal plume. For this reason, the behaviour of this kind of fire must present some similarities with pool fire. It is well known that the dynamic of pool fires is governed by thermal-convective instabilities, marked by vertical oscillations of the flame height and of the heat release rate, with a frequency $f_{B}$ related to the acceleration of gravity $(\mathrm{g})$ and the diameter $\left(\mathrm{D}_{\text {Fire }}\right)$ of the pool fire as following: 


$$
f_{B}=(0.5 \pm 0.04)\left(\frac{g}{D_{\text {Fire }}}\right)^{1 / 2}
$$

Wind driven fires are more affected by the inertia force of the wind, a consequence of that is that the dynamics of the fire can potentially be affected by the shear layer instability (Kelvin-Helmholtz) resulting from the rapid deceleration of the external flow due to the presence of the vegetation. For this reason, we have also introduced in our analysis the characteristics frequency $f_{K H}$ associated with this instability along the steamwise direction:

$$
f_{K H}=\frac{0.15 \times U_{H}}{H}
$$

where $\mathrm{U}_{\mathrm{H}}$ is the wind velocity at the top $(\mathrm{Z}=\mathrm{H})$ of the canopy.

Because the behaviour of surface fires can be affected by these two forces (the buoyancy and the inertia of the wind), we have compared the frequencies extracted from the fast Fourier transform (FFT) analysis of the fire intensity signals with these two characteristics frequencies.

\section{Results and discussion}

A first set of numerical simulations has been performed for a large range of wind velocity (from 1 to $25 \mathrm{~m} / \mathrm{s}$ ) in order to cover both, plume dominated and wind driven fires. The results shown in Figure 2 is a good illustration of the difference of interaction between the fire front and the surrounding atmosphere, for weak ( $\mathrm{UW}=1 \mathrm{~m} / \mathrm{s}$ ) and strong $(\mathrm{UW}=20 \mathrm{~m} / \mathrm{s})$ wind conditions. For weak wind conditions, the trajectory of the flame was nearly vertical, promoting the development of a vertical thermal plume forming an obstacle for the incoming wind which was not able to cross the fire front (the same tendency has also been observed in 3D for the same wind conditions [21]). The burning zone was fed in fresh air symmetrically on both side of the fire front (see Figure 2 on top).
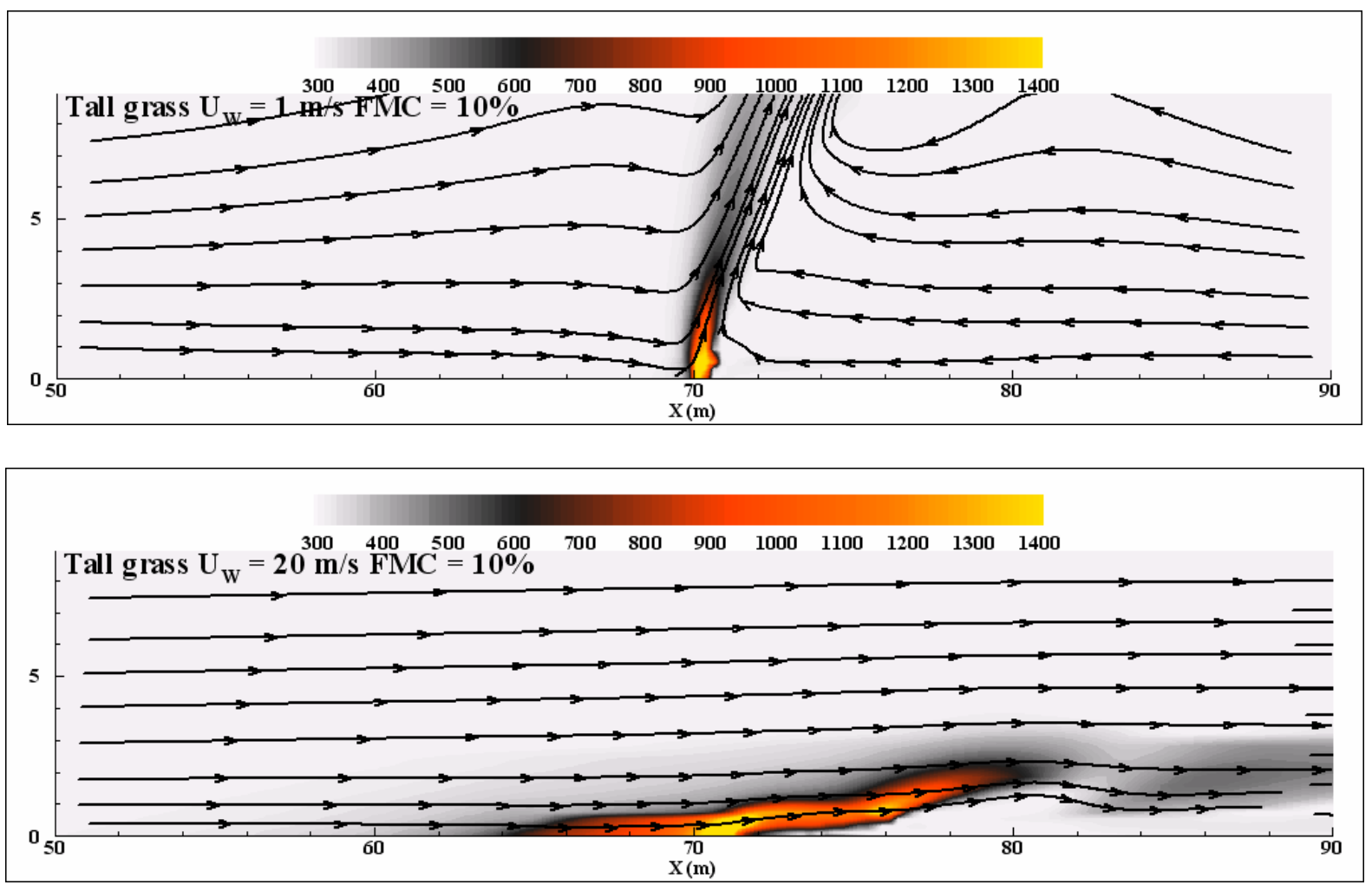

Figure 2. Snapshot of the temperature field and gas flow (streamlines) calculated for two values of the wind velocity: $U W=1$ and $20 \mathrm{~m} / \mathrm{s}$. 
We must underline that 2D simulations contribute to enforce this behaviour (in 3D the formation of peaks and troughs along the fire front [8], allowed to reduce the role of barrier played by the fire front). For strong wind conditions, the trajectory of the flame was significantly deviated by the wind flow (see Figure 2 on bottom) and the incoming wind flow was able to cross the fire front, contributing to transport hot gases from the burning zone toward the vegetation layer. As shown in Table 2, the action of the wind flow upon the fire behaviour (in terms of rate of spread and fire intensity) cannot be reduced to a monotonic curve, confirming the existence of multiple regimes of propagation. This kind of non linear interaction between wind and fire has already be observed experimentally and reported in the literature $[10,11,12]$. The signals of fire intensity obtained for the same wind conditions (UW $=1 \mathrm{~m} / \mathrm{s}$ and $20 \mathrm{~m} / \mathrm{s}$ ) are shown in Figure 3 (see also Table 2).

Between 1 and $20 \mathrm{~m} / \mathrm{s}$, the rate of spread and the fire intensity, has increased by a factor 2.8 and 2.6 respectively. An other interesting information extracted from these fire intensity signals, is the ratio between the standard deviation and the average value, which decreased from 0.28 to 0.18 (as the wind speed increases from 1 to $20 \mathrm{~m} / \mathrm{s}$ ). This trend was confirmed for the whole range of variation of the wind speed (see Figure 4), indicating that the relative level of unsteadiness of the fire behaviour was more pronounced for plume dominated fires than for wind driven fires. The same kind non-linear effect has already been observed experimentally [6] and numerically [7] for the relationship linked the rate of spread and the wind velocity. It is already known that the behaviour of plume dominated fires is more difficult to predict compared to fires piloted by a strong wind.
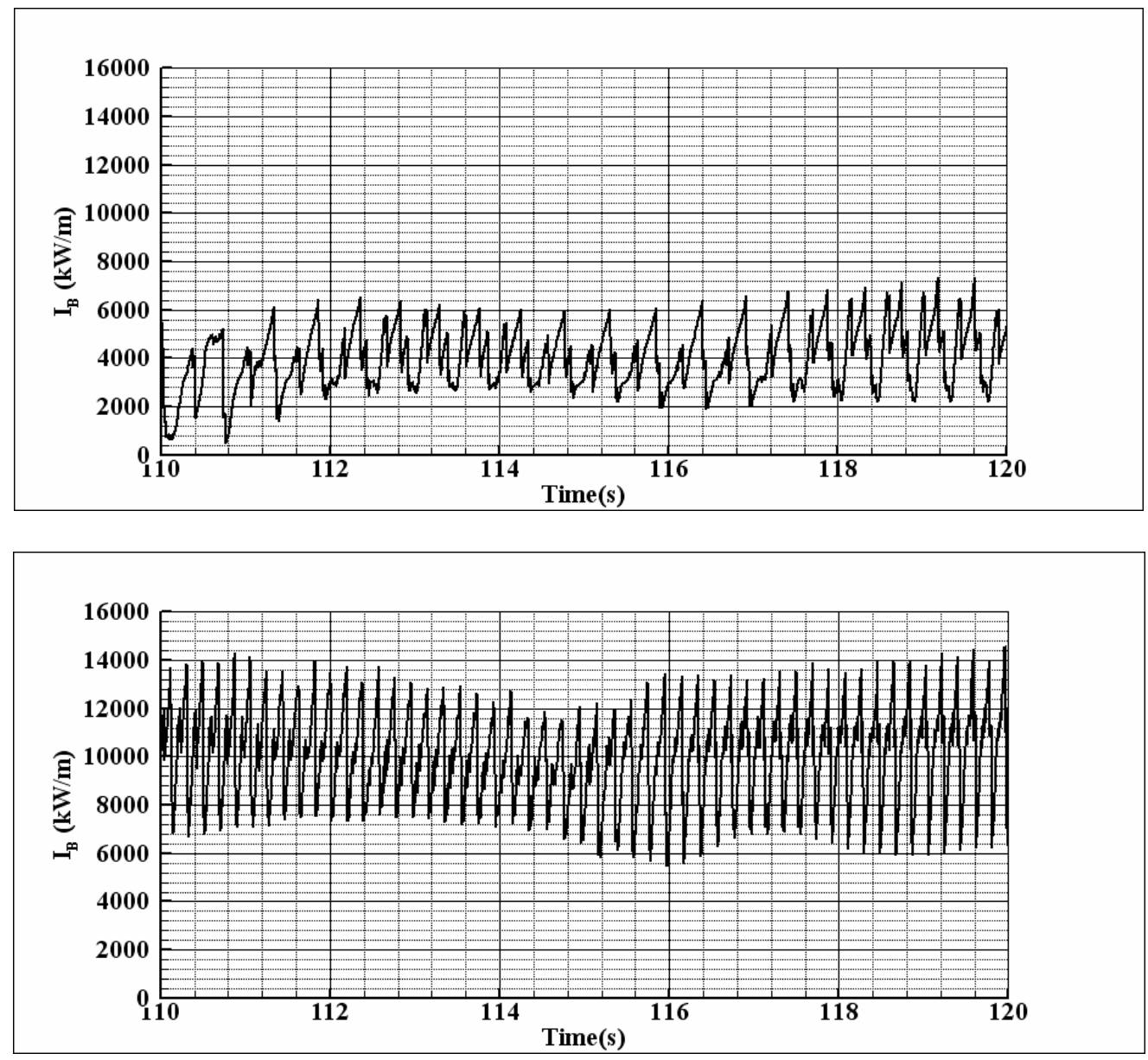

Figure 3. Time history of fireline intensity for two values of wind velocity: $U W=1$ (top) and $20 \mathrm{~m} / \mathrm{s}$ (bottom). 


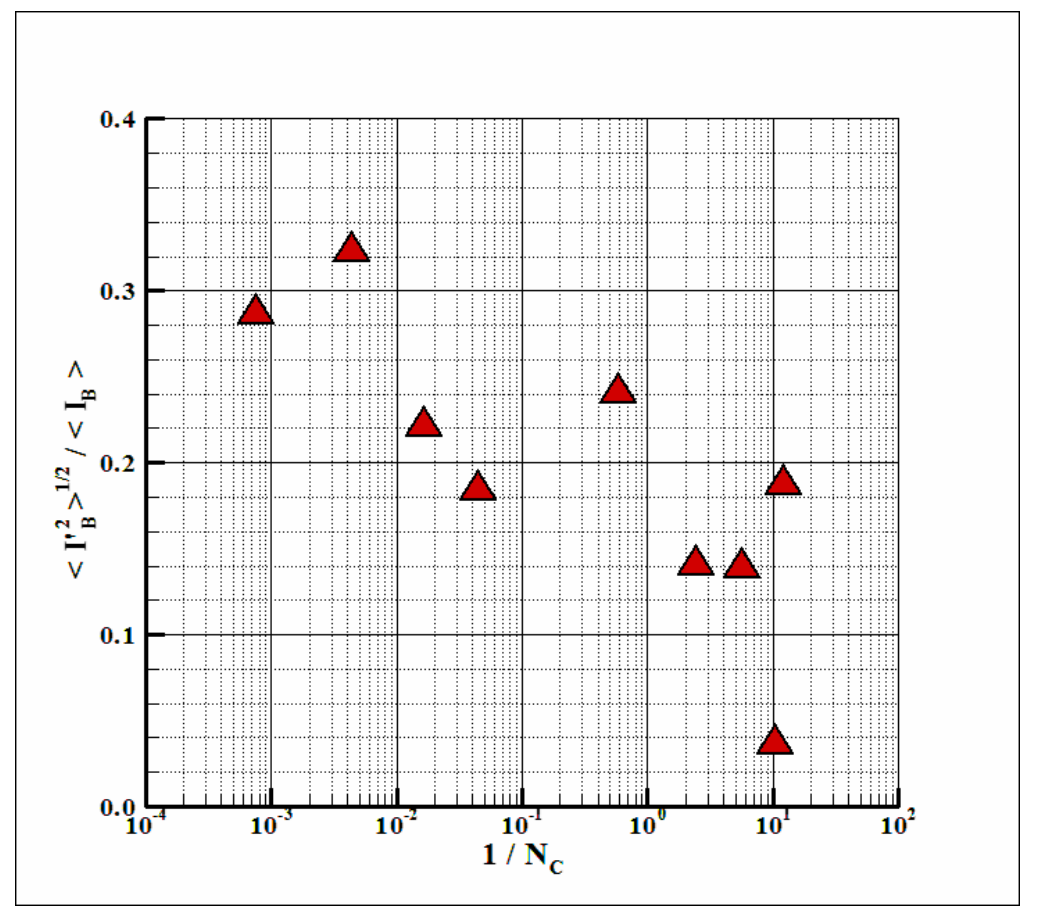

Figure 4. Ratio standard deviation / mean value of the fireline intensity as a function of the convective Byram number.

This difference of behaviour versus the wind velocity, results mainly from the dominant mechanism of heat transfer between the flame and the vegetation. If the radiation heat transfer plays a major role in the propagation of the fire, because this physical mechanism is intrinsically more non-linear compared to convection heat transfer (because of the $\sigma \mathrm{T} 4$ of the Stefan-Boltzmann law), it is not surprising that this kind of surface fire can exhibited less predictable sudden changes [12].

Fast Fourier transform (FFT) of the fire intensity signal (see an example in Figure 5) has allowed identifying the energy distribution on a frequency domain. As shown in Figure 5 , for $U W=1 \mathrm{~m} / \mathrm{s}$, the major contribution (maximum level of energy) was associated to a oto the frequency characterizing the buoyancy instability $(1.6 \mathrm{~Hz})$ compared to the Kelvin-Helmholtz instability $(0.1 \mathrm{~Hz})$.

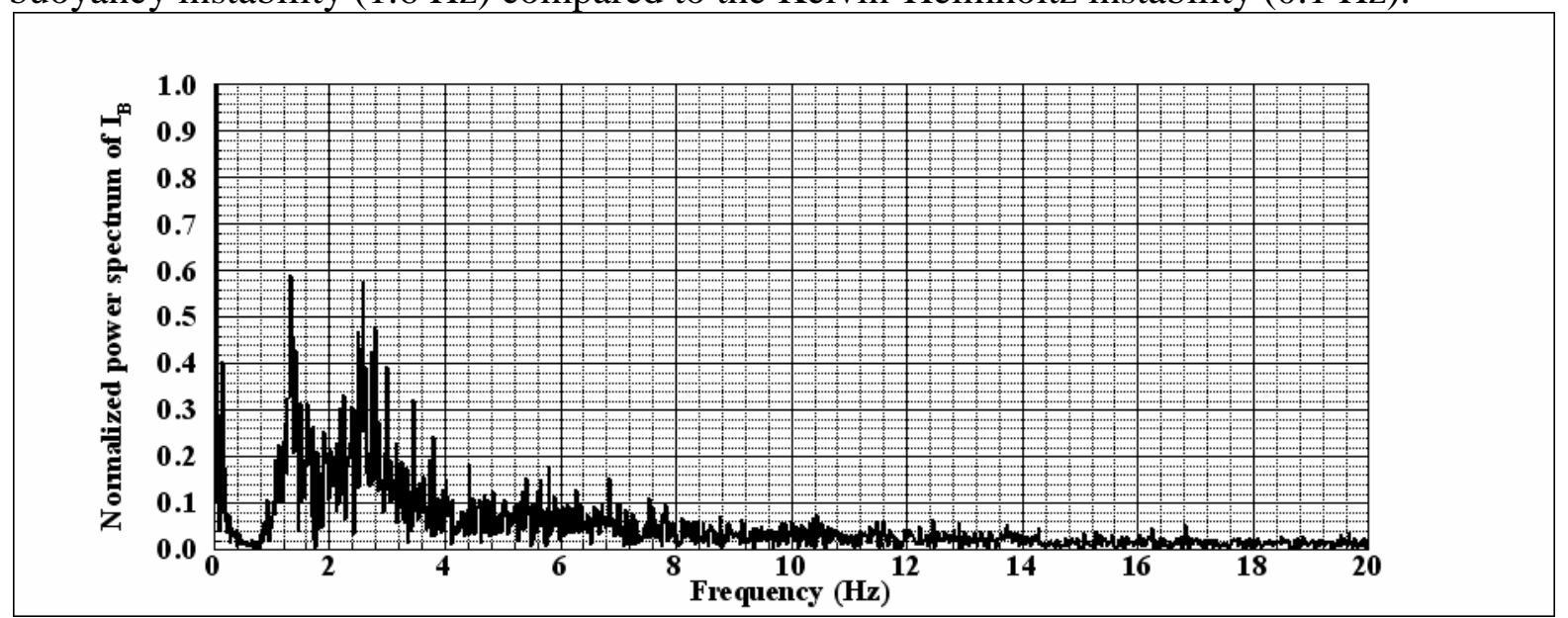

Figure 5. FFT analysis of fireline intensity signal obtained for $U_{W}=1 \mathrm{~m} / \mathrm{s}$.

In analysing the data in Table 2 and considering that the wind velocity promoted an increase of the depth of the fire front (see Figure 2), consequently its effect upon the two frequencies associated to the two forces (buoyancy and inertia) were symmetrically opposed: it decreased for the first one, and it increased for the second one. Considering that the situation observed during the propagation of a 
surface fire differed from the two simplified models used for the analysis in frequencies (steady pool fire and boundary layer canopy interaction), we can still conclude that, as the behaviour of the fire moved from plume dominated fire to wind driven fire, the instability governing the fire intensity signal, changed from a thermal-convective type instability to a shear type instability.

In order to study the response of a surface fire in propagation, we have performed a second set of simulations, in adding a sinusoidal variation, in order to reproduce schematically wind gusts.

$$
U_{X}(z)=A \times U_{W} \times \operatorname{Ln}\left(\frac{z+z_{0}}{z_{0}}\right)+\Delta U_{W} \sin (2 \pi \times F \times t)
$$

where $\Delta \mathrm{U}_{\mathrm{W}}$ and $\mathrm{F}$ are respectively the amplitude and the frequency of wind variations. The present study has been limited to one wind conditions $U_{W}=2 \mathrm{~m} / \mathrm{s}$ and $\Delta U_{W}=1 \mathrm{~m} / \mathrm{s}$ (the wind speed varied between 1 and $3 \mathrm{~m} / \mathrm{s}$ ), the frequency $F$ varied between 0.25 and $3 \mathrm{~Hz}$. This wind condition $\left(U_{W}=2 \mathrm{~m} / \mathrm{s}\right)$ has been chosen because it represented a situation for which we have found (in quasi steady wind conditions) a relatively high value of the variation of the rate of spread (ROS) versus $U_{W}$ (see Table 2).

Table 2. Wind speed, Rate of spread, Fire intensity (average value, standard deviation, frequency), Thermalconvective and Kelvin-Helmholtz frequencies.

$\begin{array}{cccccccccc}\mathrm{UW}(\mathrm{m} / \mathrm{s}) & 1 & 2 & 3 & 4 & 8 & 12 & 15 & 20 & 25 \\ \mathrm{ROS}(\mathrm{m} / \mathrm{s}) & 0.46 & 0.84 & 1.06 & 1.18 & 1.24 & 1.23 & 1.10 & 1.28 & 2.51 \\ \mathrm{IB}(\mathrm{kW} / \mathrm{m}) & 3798 & 6468 & 8179 & 9155 & 9604 & 9331 & 8602 & 9913 & 20098 \\ <\mathrm{I} \text { 'B }>1 / 2 & 1088 & 2090 & 1806 & 1683 & 2313 & 1311 & 1191 & 1856 & 738 \\ (\mathrm{~kW} / \mathrm{m}) & & & & & & & & & \\ \mathrm{f}(\mathrm{Hz}) & 2.3 & 3.4 & 4.2 & 4.8 & 5.0 & 5.0 & 5.5 & 5.5 & 5.5 \\ \mathrm{fB}(\mathrm{Hz}) & 1.6 & 1.4 & 1.2 & 1.1 & 0.9 & 0.8 & 0.7 & 0.6 & 0.5 \\ \mathrm{fKH}(\mathrm{Hz}) & 0.1 & 0.2 & 0.4 & 0.5 & 3.2 & 1.1 & 1.6 & 2.0 & 2.6\end{array}$

The curve shown in Figure 6 is the time evolution of the fire intensity obtained with a sinusoidal variation at a frequency of $0.25 \mathrm{~Hz}$, in comparison we have also added the result obtained in quasisteady wind conditions. 


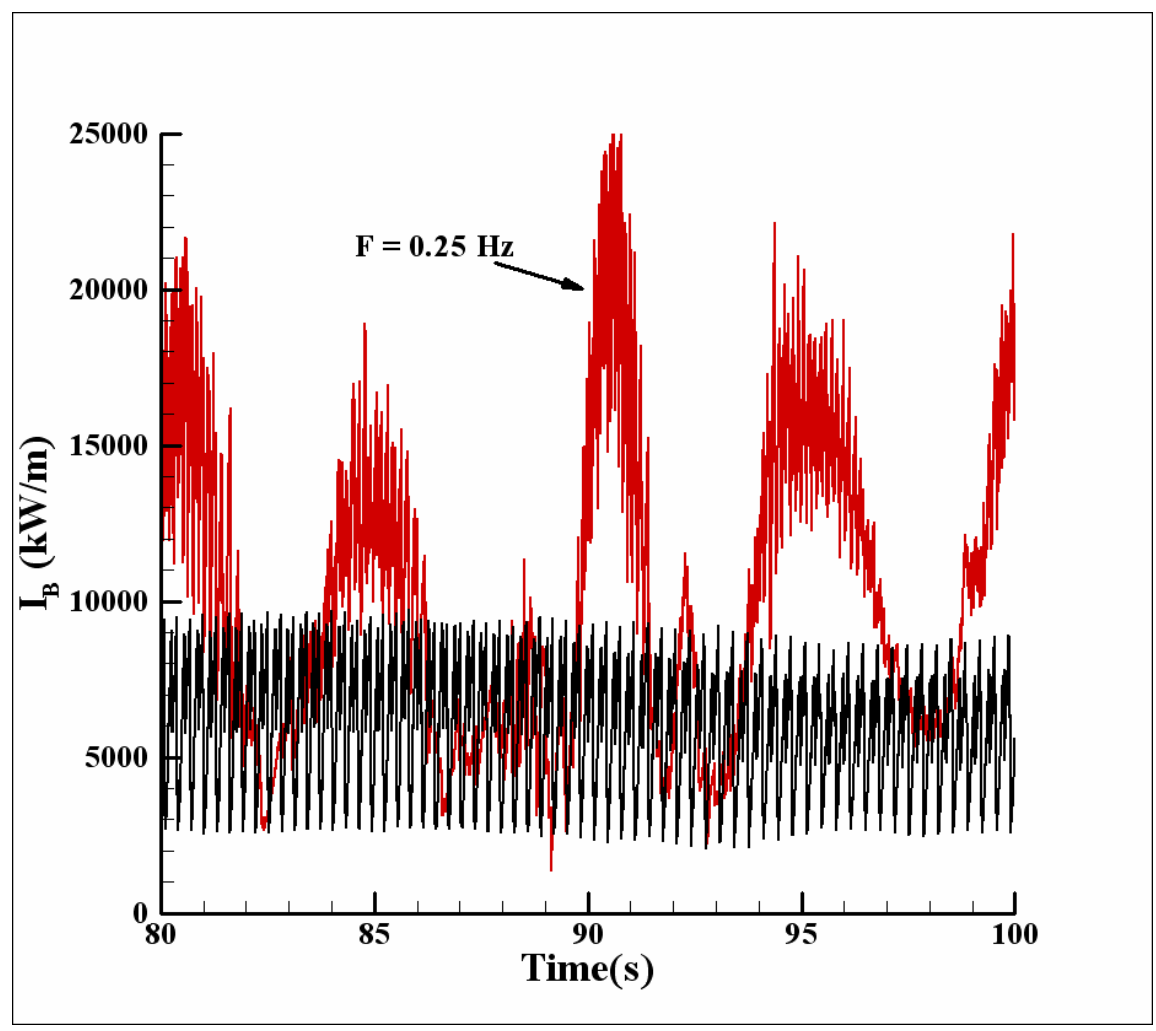

Figure 6 -Time evolution of the fireline intensity obtained for $U_{W}=2 \mathrm{~m} / \mathrm{s}$ with and without a sinusoidal variation $(F=$ $0.25 \mathrm{~Hz}$ ).

This is for this frequency $(0.25 \mathrm{~Hz})$, nearly equal to the frequency characterizing the Kelvin-Helmholtz instability (see Table 2) that we have obtained the maximum effect. We can notice that this relatively small change in wind conditions, has promoted a huge modification of the behaviour of the fire. While the maximum value observed in quasi-steady state varied from 7000 to $12000 \mathrm{~kW} / \mathrm{m}$, for a wind velocity ranging between 1 and $3 \mathrm{~m} / \mathrm{s}$, the same value has increased up to $20000-25000 \mathrm{~kW} / \mathrm{m}$ (the fire intensity signal was modulated with a sinusoid at frequency of $0.21 \mathrm{~Hz}$ ) in simply adding an unsteady variation. We have also noticed that this sort of resonance mechanism decreased rapidly as the excitation frequency exceeded this critical value, the maximum fire intensity observed with a frequency $\mathrm{F}=0.5 \mathrm{~Hz}$ reached $18000 \mathrm{~kW} / \mathrm{m}$ and decreased to $10000 \mathrm{~kW} / \mathrm{m}$ for $\mathrm{F}=1 \mathrm{~Hz}$ (quasi identical than the value observed in quasi steady wind conditions for $U_{W}=2 \mathrm{~m} / \mathrm{s}$ ).

The normalized spectra of the fire intensity signals shown in Figure 7, has confirmed this coupling mechanism between the frequency at which the wind velocity was excited and the characteristic frequency of the Kelvin-Helmhotz instability. The evolution of the fire intensity (average value and standard deviation) as a function of the wind gusts frequency $\mathrm{F}$ is represented in Figure 8.

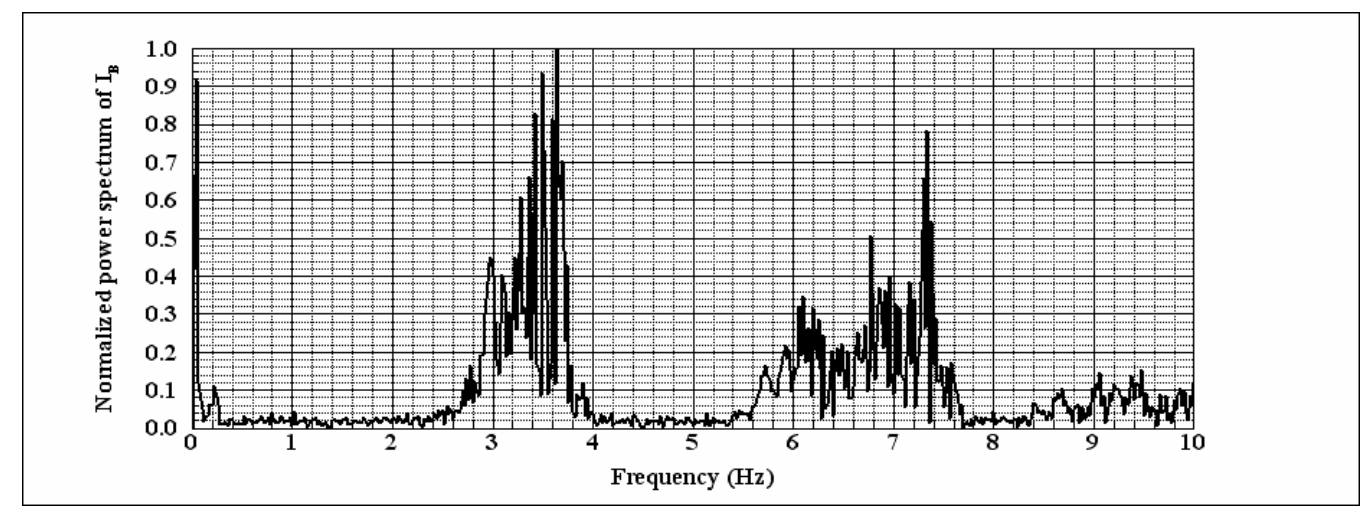




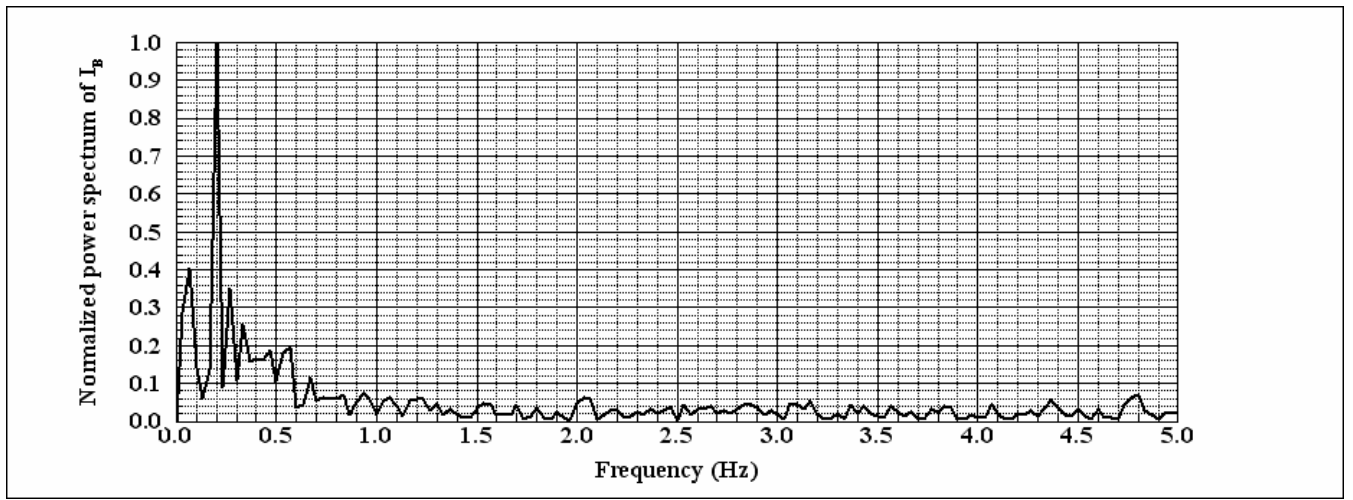

Figure 7. FFT analysis of fireline intensity signal obtained for $U_{W}=2 \mathrm{~m} / \mathrm{s}$ without (top) and with (bottom) a sinusoidal time variation (amplitude $2 \mathrm{~m} / \mathrm{s}$, frequency $0.25 \mathrm{~Hz}$ ).

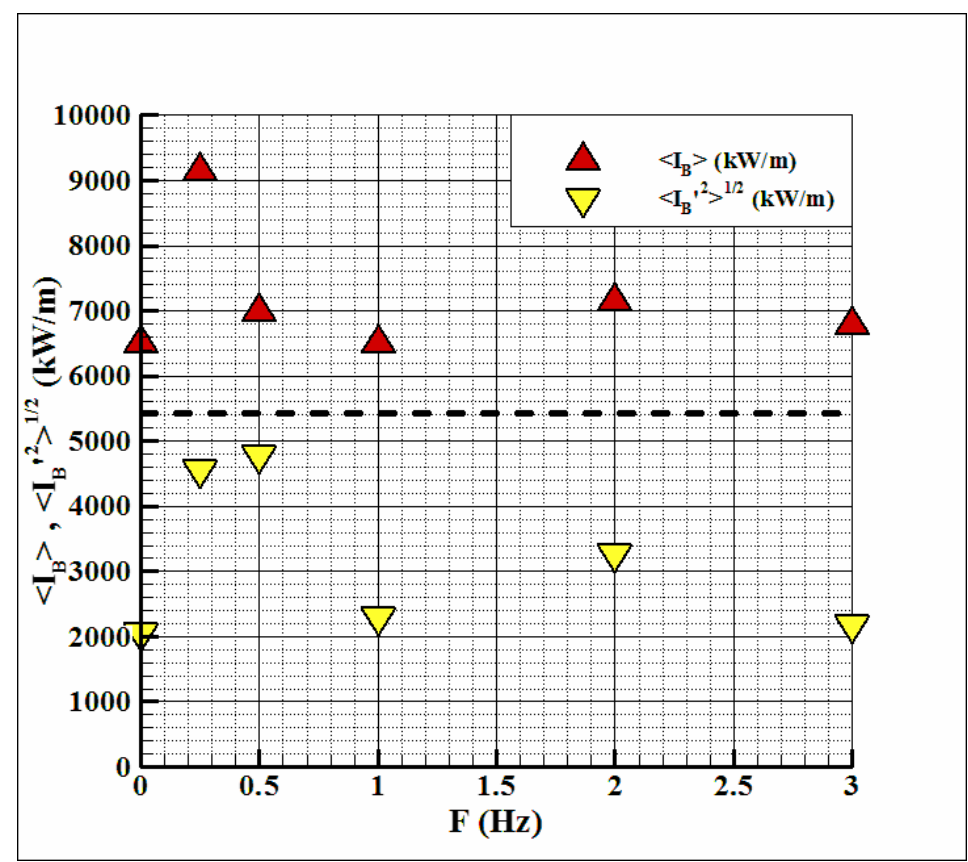

Figure 8. Fireline intensity and standard deviation obtained for $U W=2 \mathrm{~m} / \mathrm{s}$ and a sinusoidal time variation (frequency ranged between $0.25 \mathrm{~Hz}$ and $3 \mathrm{~Hz}$ ).

These numerical data show that two frequencies seemed increasing the unsteady effects, a first one (with the larger effect) for $\mathrm{F}=0.25 \mathrm{~Hz}$ (near the Kelvin-Helmoltz frequency for these conditions of wind and vegetation) and a second one for $\mathrm{F}=2 \mathrm{~Hz}$ (not far from the plume instability).

\section{Conclusion}

Numerical simulations of surface fires propagating through homogeneous vegetation layer on a flat terrain have been carried out for a large range of wind conditions, covering the two regimes of propagation (plume dominated and wind driven) referenced in the literature. The FFT analysis of the time variation of the fireline intensity signals, has allowed identifying that the unsteady motions of the flame front were governed by two instabilities (by shear and by density gradient). Then a second set of numerical simulations, reproducing the wind gusts, has allowed to highlight a coupling mechanism between forced and internal instability modes, which was able to modify significantly the fire behaviour. 


\section{References}

[1] Rothermel R.C., Anderson H.E. Fire spread characteristics determined in the laboratory USDA Forest Service RP INT-30, 1966.

[2] Catchpole W.R., Catchpole E.A., Butlet B.W., Rothermel R.C., Morris G.A., Latham D.J. Rate of spread of free-burning fires in woody fuels in a wind tunnel, Combustion Science and Technology, Vol.131, pp.1-37, 1998.

[3] Trabaud L. Etude du comportement du feu dans la garrigue de chêne kermès à partir des températures et des vitesses de propagation, Annals of Forest Science, Vol.36(1), pp.13-38, 1979.

[4] Fernandes P.A.M. Fire spread prediction in shrub fuels in Portugal, Forest Ecology and Management, Vol.144, pp.67-74, 2001.

[5] McArthur A.G. Weather and grassland fire behaviour, Forest Research Institute, Forestry and Timber Bureau, ACT, Australia, 1966.

[6] Fogarty L.G., Alexander M.E. A field guide for predicting grassland fire potential, Fire Technology Transfer Note, Vol.20, 10p., 1999.

[7] Morvan D., Dupuy J.L. Modeling the propagation of a wildfire through a Mediterranean shrub using a multiphase formulation, Combustion and Flame, Vol.138, pp.199-210, 2004.

[8] Beer T. The interaction of wind and fire, Boundary-Layer Meteorology, Vol.54, pp.287-308, 1991.

[9] Morvan D. Physical phenomena and length scales governing the behaviour of wildfires: a case for physical modelling, Fire Technology, Vol.47, pp.437-460, 2011.

[10] McArthur A.G. The Tasmanian bushfire of $7^{\text {th }}$ February 1967, and associated fire behaviour characteristics. Technical Co-operation Programme, Mass Fire Symposium (Canberra, Australia 1969), Maribyrnong, Victoria, Defence Standards Laboratories, Vol.1, 23p, 1969.

[11] Rothermel R.C. A mathematical model for predicting fire spread in wildland fuels, USDA Forest Service RP INT-115, 43p., 1972.

[12] Morvan D., Meradji S., Accary G. Physical modelling of fire spread in grasslands, Fire Safety Journal, Vol.44, pp.50-61, 2009.

[13] Morvan D. Wind effects, unsteady behaviour and regimes of propagation of surface fires in open field. Combustion Science and Technology, (in press), 2014.

[14] Grishin A.M. Mathematical modelling of forest fires and new methods of fighting them. Albini F. (Ed.) Tomsk State University, 367p., 1997.

[15] Libby P.A., Williams F.A. Turbulent reacting flows. Academic Press, 1994.

[16] Anderson, H.E. Aids to determining fuel models for estimating fire behaviour, Gen. Tech. Rep. INT-122, Ogden UT, USDA-FS, Intermountain Research Station, 22p., 1982.

[17] Morvan D., Larini M. Modeling of one dimensional fire spread in pine needles with opposing air flow, Combustion Science and Technology, Vol.164, pp.37-64, 2001.

[18] Cox G. Combustion fundamentals of fire. Academic Press, London, 1995.

[19] Hamins A., Kashiwagi T., Burch R.R. Characteristics of pool fire burning. ASTM STP 1284, 1996.

[20] Kaimal J.C., Finnigan J.J. Atmospheric boundary layer flows, Oxford University Press, 1994.

[21] Morvan D., Méradji S., Mell W. Interaction between head fire and backfire in grasslands, Fire Safety Journal, Vol.58, pp.195-203, 2013. 